\title{
TRICHOGLOTTIS CORAZONIAE (ORCHIDACEAE: VANDEAE: AERIDINAE), A NEW SPECIES FROM THE PHILIPPINES
}

\author{
Mark Arcebal K. Naive ${ }^{1,3} \&$ John Clifton Martyr ${ }^{2}$ \\ ${ }^{1}$ Department of Biological Sciences, College of Science and Mathematics, Mindanao State University - \\ Iligan Institute of Technology, Andres Bonifacio Ave, Iligan City, 9200 Lanao del Norte, Philippines \\ ${ }^{2}$ Department of Microbiology and Parasitology, College of Medicine, University of St. La Salle, \\ La Salle Avenue, Bacolod City, Negros Occidental, 1600, Philippines \\ ${ }^{3}$ Corresponding author: arciinaive19@gmail.com
}

\begin{abstract}
A new species of Trichoglottis, T. corazoniae, apparently endemic to Negros island, is here described and illustrated. It is closely similar to $T$. tamesisii but distinct by having forward-pointing stelidia with the upper surface being pubescent, larger flowers and a longer inflorescence. Information on the distribution, ecology and phenology are provided.
\end{abstract}

KeY words: Aeridinae, endemic, Negros Occidental, new species, Orchidaceae, Philippines

Introduction. The genus Trichoglottis Blume (1825: 3590) was establised by Dr. Carl Blume in Bijdragen tot de Flora van Nederlandsch Indie in 1825. The designated type species of this genus is Trichoglottis retusa Blume. There are approximately 70 species in the genus which are distributed in the Himalayas, Union of Myanmar (Burma), Thailand, Peninsular Malaysia, Laos, Kampuchea (Cambodia), Vietnam, Indonesia, Borneo, Sulawesi (Celebes), New Guinea, the North of Australia, the islands of the Pacific and the Philippines, with about 22 species (Cootes 2011, Pelser et al. 2017).

Several unknown Trichoglottis plants were first seen in the collection of Mr. Josef Sagemuller in Tabucol, Murcia, Negros Occidental in 2014. In April 2016, three blooming plants were found in a garden by the main highway in Don Salvador Benedicto by the second author. A search for additional plants revealed that the plants can be found in the remaining forested areas of the Northern Negros Natural Park which is bounded by several cities and municipalities of the northern portion of Negros Island. Pictures of the flowers were sent then to the first and third author and they suspected that it could be an undescribed species. After a careful examination of its morphology and comparative study of relevant literature from the Philippines and neighboring countries, it turned out that the collected specimen does not match any other known Trichoglottis species. We hereby take this opportunity to describe this orchid as Trichoglottis corazoniae, a species new to science.

Materials and Methods. The measurements and descriptions were based on fresh, dried, and spirit materials. The terminology in general follows Beentje (2016). Flowers were preserved in formalin-aceticacid-alcohol (FAA) for further study. All original materials under Trichoglottis from the Philippines were examined in different herbaria through high resolution images accessed at https://plants.jstor.org/. Detailed descriptions and coloured photographs of this new species as well as notes on its distribution, phenology, and ecology are provided.

\section{TAXONOMIC TREATMENT}

\section{Trichoglottis corazoniae Naive \& Martyr, sp. nov.}

TYPE: Philippines. Visayas, Negros Occidental, Municipality of Don Salvador Benedicto, Northern Negros Natural Park, elevation $700 \mathrm{~m}$ asl, 12 April 2016, M. A. Naive 024/2017 (holotype, CMUH; isotype, HNUL). Fig. 1-3b.

Diagnosis: Trichoglottis corazoniae is closely allied to T. tamesisii Quisumb. \& C.Schweinf., however, 
it differs significantly in having a forward-pointing stelidia with the upper surface being pubescent ( $v s$. stelidia which are upward-pointing with glabrous upper surface), an upright convex dorsal sepal with truncate apex ( $v s$. nodding or arching, concave, apex rounded dorsal sepal), larger flower and a longer inflorescence (50 cm long vs. $25 \mathrm{~cm}$ long). It also differs in the coloration of the flowers and in having a downwards-pointing, puberulous labellum ( $v s$. porrect, pubescent labellum). This new species is also comparable to T. ionosma (Lindl.) J.J.Sm. ex Hayata, however, it differs significantly in the shape of the midlobe of labellum (lanceolate vs. heart-shape), colour of the flowers (greenish yellow to yellow with or without reddish brown patches flowers $v s$. brown, edges of segments yellow flowers), an erect dorsal sepal and petals ( $v s$. nodding or arching petals and dorsal sepal) and in having a glabrous column (vs. pubescent column).

Monopodial, upright, epiphytic, clumping herb. Roots thick, terete, glabrous, up to $0.4 \mathrm{~cm}$ in diameter. Stems cylindrical, up to $55 \mathrm{~cm}$ long, covered with leaf sheaths. Leaves elliptic to oblong, sessile, green, leathery, two ranked, glabrous, $18-23 \times 4.0-4.5 \mathrm{~cm}$, margin entire, apex unequally bilobed. Inflorescence paniculate, lax, 1-3 branches, upright, dichotomously branching, longer than the leaves, up to $50 \mathrm{~cm}$ long, bearing up to 20 fragrant blooms. Pedicel with ovary sulcate, twisted, $1.5-1.7 \times 0.15 \mathrm{~cm}$. Flower 3.5-4.0 $\mathrm{cm}$, greenish yellow to yellow with or without reddish brown patches. Dorsal sepal narrowly obovate, truncate to slightly emarginate, slightly convex, glabrous, fleshy, $1.5-1.8 \times 0.7-0.9 \mathrm{~cm}$. Lateral sepals narrowly obovate, rounded slightly convex, glabrous, slightly fleshy, $1.3-1.6 \times 0.5-0.7 \mathrm{~cm}$. Petals oblanceolate to narrowly obovate, rounded, slightly falcate, glabrous, fleshy, sometimes slightly recurved, $1.5-1.7 \times 0.5-0.7$ $\mathrm{cm}$. Labellum trilobed, lanceolate when viewed from above, fleshy, puberulous on the upper surface, 1.5-1.8 $\times 0.4-0.5 \mathrm{~cm}$, with a thickened ridge centrally and a short spur basally, pointing downwards at a slight angle from the vertical; lateral lobes erect, squarish, apex subtruncate; midlobe relatively large, lanceolate, with a stout, fleshy, densely pilose callus in the upper surface, rostrate, upper surface of the rostrum pubescent; spur saccate, short, $0.4-0.5 \mathrm{~cm}$ long. Column stout, short, rostellate, porrect, bearing two short narrowly triangular falcate porrect arms located below the stelidia, with two stelidia; stelidia porrect, narrowly triangular, pointing forward, 0.3-0.4 $\times 0.1$ $\mathrm{cm}$, outer surface pubescent. Anther cap $2 \times 3 \mathrm{~mm}$, apex bilobulate. Pollinia oblate, $1 \times 1 \mathrm{~mm}$. Fruits and seed not seen.

Eponymy: Named after Mrs. Corazon Montilla Sagemuller, mother of Mr. Josef Sagemuller, who first brought the plants to the attention of the authors.

Distribution: This Philippine endemic species has only been observed and documented in the Northern

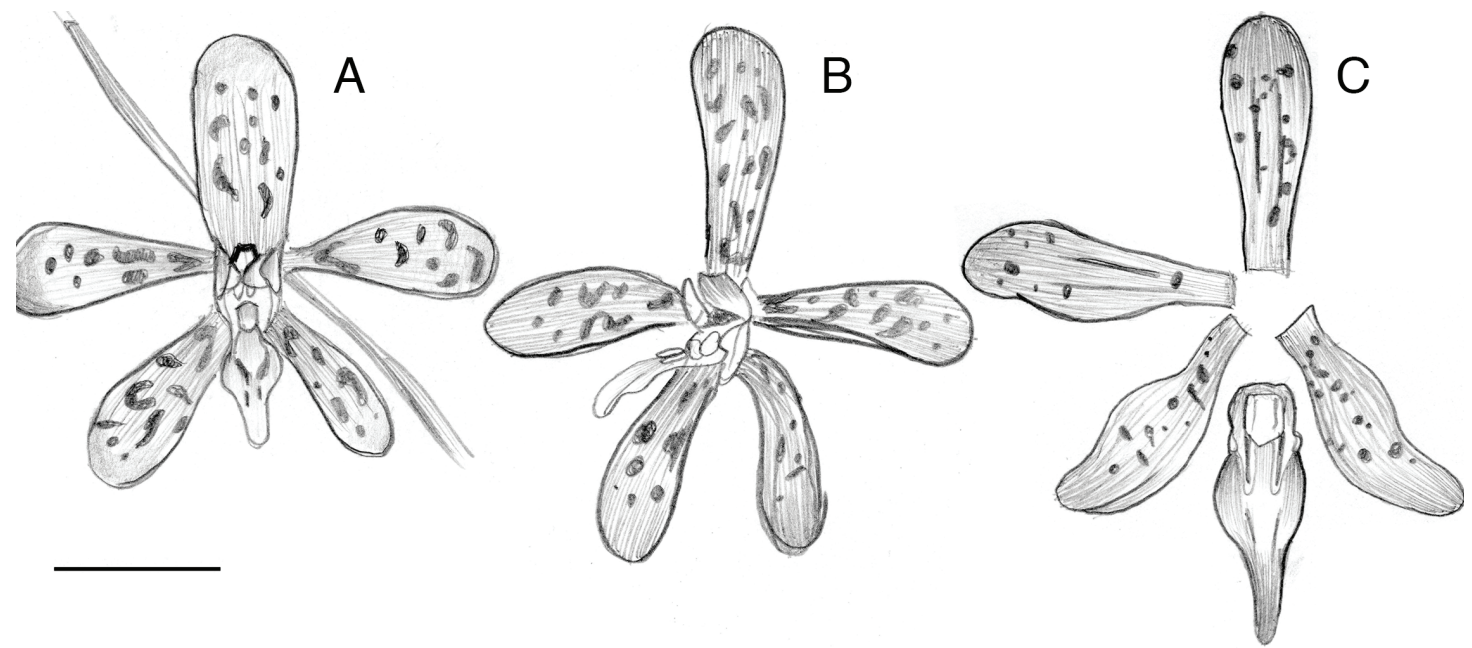

Figure 1. Trichoglottis corazoniae. Flower in frontal (A) and three quarters views (B). C. Perianth, flattened. Drawn by Belson Esponilla Amsicua from M.A. Naive 024/2017. Scale bar $=1 \mathrm{~cm}$. 


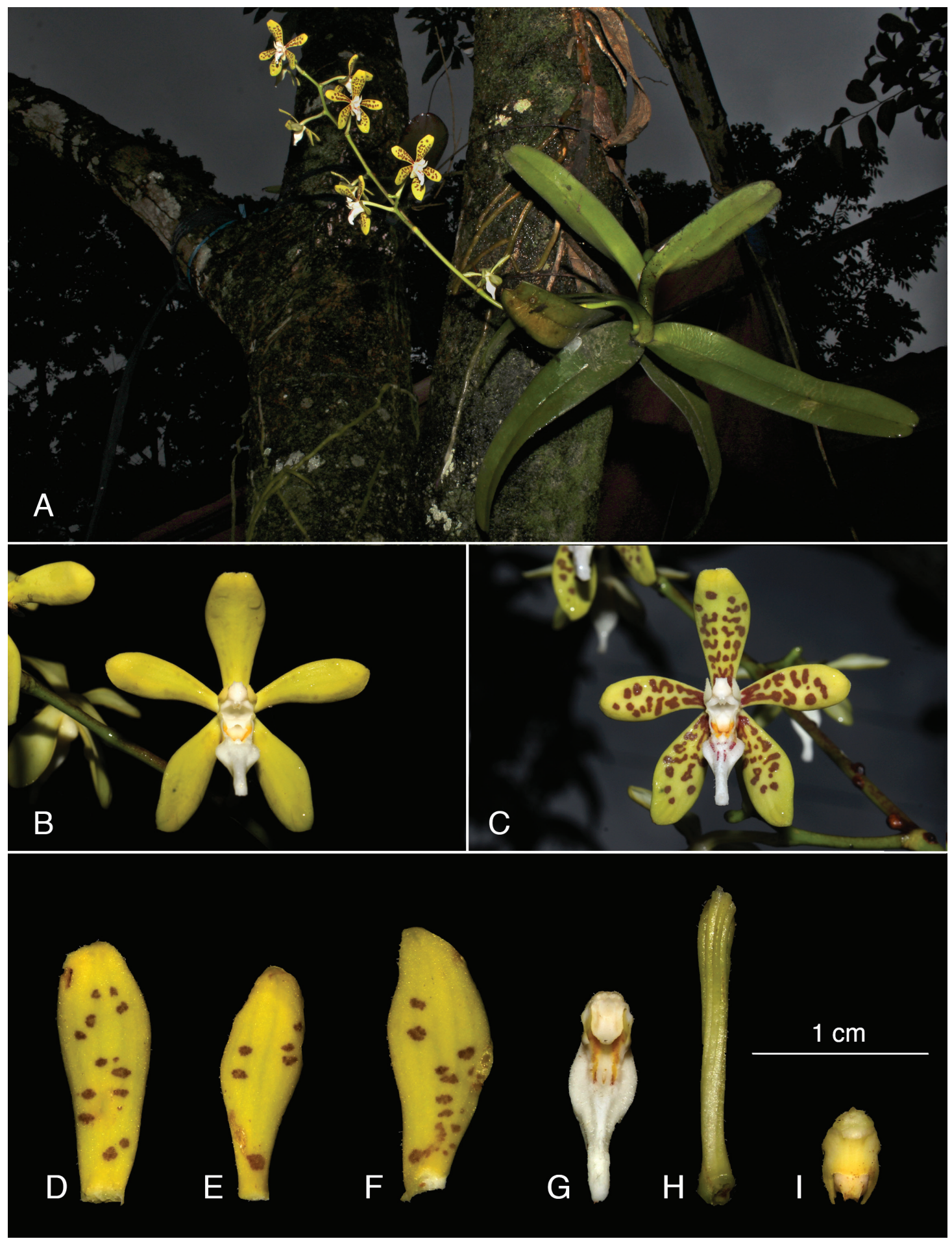

Figure 2. Trichoglottis corazoniae. A. Habit. B-C. Flower color variations. D-I. Dissected flower. D. Dorsal sepal. E. Petal. F. Lateral sepal. G. Labellum. H. Pedicel and ovary. I. Column and stelidia. Photographs by Mark Arcebal K. Naive from M.A. Naive 024/2017. 


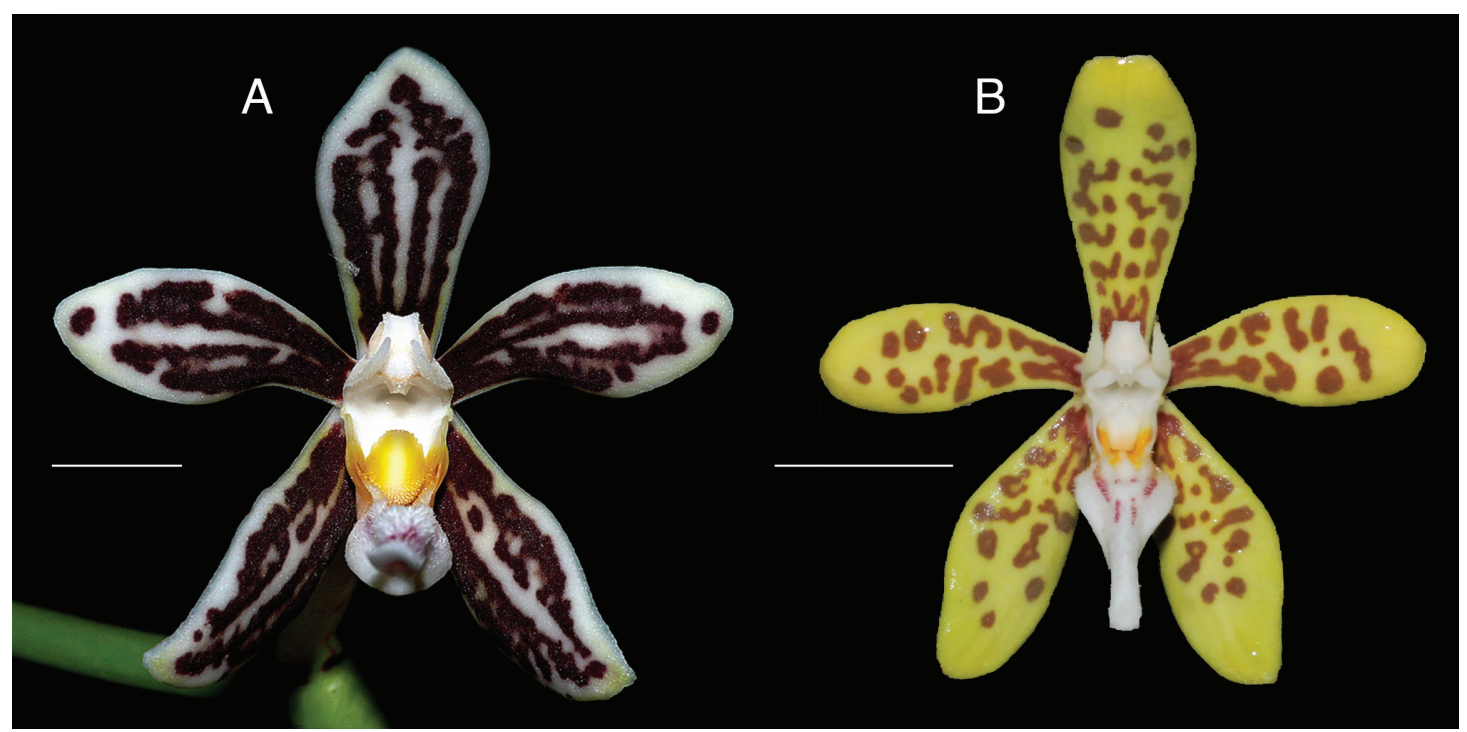

Figure 3. Flower comparison. A. T. tamesisii. B. T. corazoniae. Scale bars: A $=2 \mathrm{~cm} ; \mathrm{B}=4 \mathrm{~cm}$. Photographs by Ravan Schneider (A) and Mark Arcebal K. Naive (B).

Negros Natural Park, Municipality of Don Salvador Benedicto, Negros Occidental.

ECOLOGY: Epiphytic in primary or secondary montane forest in half shady to brightly lit positions at 700$1000 \mathrm{~m}$

Phenology: Observed flowering under cultivation from April to June.

CONSERVATION StATUS: There is no adequate information to make a direct or indirect assessment of its risk of extinction based on its distribution and/or population status. Following the Red List Criteria of the IUCN (2012), we herein consider Trichoglottis corazoniae as Data Deficient.

Based on overall morphology, Trichoglottis tamesisii appears to be the closest ally of T. corazoniae. However, it differs significantly in having a pointing upwards stelidia with the upper surface being pubescent ( $v s$. stelidia which are pointing toward each other with glabrous upper surface), an upright convex dorsal sepal with truncate apex (vs. nodding or arching, concave, apex rounded dorsal sepal), larger flowers and a longer inflorescence (50 cm long vs. 25 $\mathrm{cm}$ long). It also differs in the coloration of the flowers and in having a pointing downwards, puberulous labellum ( $v s$. porrect, pubescent labellum). This new species is superficially resembles T. ionosma, however, it differs significantly in the shape of the midlobe of labellum (lanceolate $v s$. heart-shape), colour of the flowers (greenish yellow to yellow with or without reddish brown patches flowers vs. brown, edges of segments yellow flowers), an erect dorsal sepal and petals (vs. nodding or arching petals and dorsal sepal) and in having a glabrous column (vs. pubescent column).

ACKNOwLEDGEMENTS. This study was conducted in partnership with Philippines Biodiversity Conservation Foundation, Inc. (PBCFI) through Mr. Godfrey Jakosalem and League of Orchid Conservationists Philippines, Inc. (LOCPhil). We also thank Jim Cootes, Daniel Geiger, Mark Clements, Josef Sagemuller, Ravan Schneider, Belson Esponillo Amsicua and Ricarido Marquez for their valuable help in completing this manuscript.

Literature CITED

Beentje, H. (2016). The Kew Plant Glossary, an illustrated dictionary of plant terms (Second edition). Royal Botanic Gardens, Kew: Kew Publishing.

Cootes, J. (2011). Philippine Native Orchids Species. Philippines: Katha Publishing Co., Inc.

JSTOR. (2017). Global Plants. Retrieved from http://plants. jstor.org/ [Accessed 2 June 2017].

Pelser, P. B., Barcelona, J. F. \& Nickrent, D.L. (eds.). (2017). Co's Digital Flora of the Philippines. Retrieved from www. philippineplants.org. [Accessed 2 June 2017]. 